\title{
Ocena działalności naukowo-badawczej ośrodków geograficznych w Polsce
}

\section{Jerzy Bański $\odot$ Barbara Solon}

Instytut Geografii i Przestrzennego Zagospodarowania im. S. Leszczyckiego PAN

ul. Twarda 51/55, 00-818 Warszawa

jbanski@twarda.pan.pl•b.solon@twarda.pan.pl

\section{Wstęp}

Trudno dziś sobie wyobrazić ocenę ośrodków akademickich, czasopism naukowych lub dorobku pojedynczych naukowców bez wskaźników bibliometrycznych oraz innych mierników uwzględniających ważne osiągnięcia naukowe, działalność projektową lub wdrożone technologie i patenty. Na świecie powstały globalne rankingi, które na bieżąco tworzą wielokryterialne ewaluacje ośrodków akademickich i innych jednostek naukowo-badawczych. Należą do nich np.: Academic Ranking of World Universities, Times Higher Education World University Ranking, QS World University Rankings, Ranking Web of Universities, CHE-Excellence Ranking, które są odrębnym tematem licznych opracowań naukowych (np. Aguillo i inni, 2010; Cantwell i Taylor, 2013; Jöns i Hoyer, 2013; Millot, 2015; Safon, 2013). W Polsce podobny ranking uczelni jest corocznie przygotowywany przez Wydawnictwo Edukacyjne Perspektywy.

Rankingi uczelni wyższych stanowią m.in. drogowskaz dla studentów i kandydatów na studia w wyborze miejsca i kierunku studiów. Pomimo krytyki związanej z nadmierną arbitralnością i subiektywizmem, ich popularność z roku na rok wzrasta (Docampo, 2011; O 'Connell 2013; Millot, 2014;). Ważną rolę odgrywają również bazy ewaluacji i przeglądarki internetowe czasopism i ludzi nauki (np. SCOPUS, Web of Science, Google Scholar, itp.). Instytucje tworzące takie bazy są współcześnie wielkimi i dochodowymi przedsiębiorstwami kształtującymi często krajobraz edukacji na poziomie wyższym i kierunki rozwoju światowej nauki (Roberts i Thomson, 2007; Thakur, 2007).

Rankingi i ewaluacje nauki mają szczególny wymiar praktyczny. Przykładem jest ich wykorzystanie na rodzimym rynku naukowym. Wskaźniki bibliometryczne, w tym indeks Hirscha lub impact factor czasopism, w których ukazują się określone artykuły naukowe, stanowią ważny składnik oceny dorobku naukowego badaczy aspirujących do stopni naukowych i tytułu naukowego. Polskie czasopisma naukowe również poddawane są ewaluacji, a jej rezultatem jest przypisanie im odpowiednich wskaźników punktowych. Wskaźniki te mają i będą miały coraz większe znaczenie w rozwoju czasopism; w wielu przypadkach zdecydują o sukcesie lub porażce wydawniczej. Wreszcie ocenie poddawane są również ośrodki naukowe i od niej zależy głównie wartość przyznanej subwencji na działalność 
naukowo-badawczą. Ewaluacja może zatem zdecydować o „być albo nie być” instytutów naukowych.

Analizy ewaluacyjne pojawiają się od czasu do czasu w polskiej literaturze geograficznej. Są to zazwyczaj prace podejmujące problematykę oddziaływania ośrodków geograficznych (Bajerski, 2008; Bański, 2010; Śleszyński, 2013) lub oceniające kadrę naukową działającą w tych ośrodkach (Bański, 2015, 2017; Racki, 2001). Opracowania wykorzystują przede wszystkim bazy związane z czasopismami naukowymi i koncentrują się na analizie cytowań artykułów naukowych. Sporadycznie pojawiają się też proste porównania innych cech charakteryzujących jednostki geograficzne. Brakuje natomiast kompleksowych ewaluacji ujmujących szerszy zakres działalności ośrodków akademickich. Celem tego opracowania jest ocena geograficznych jednostek naukowo-badawczych, uwzględniająca dorobek publikacyjny, projektowy oraz osiągnięcia i dynamikę kariery zawodowej ich pracowników. Autorzy zajmują się wyłącznie działalnością naukową jednostek i nie uwzględniają składnika edukacyjnego (tj. warunków kształcenia, umiędzynarodowienia studiów, liczby kandydatów na studia, przebiegu karier zawodowych absolwentów, itp.). Próba oceny działalności naukowo-badawczej ośrodków geograficznych jest poważnym wyzwaniem, co wynika zarówno z trudności w uzyskaniu porównywalnych danych służących ewaluacji, jak i wspomnianego już braku literatury.

\section{Materiał badawczy i metoda}

W opracowaniu wykorzystujemy przede wszystkim dwie bazy danych dotyczące polskiej nauki, gromadzone i udostępniane przez Ośrodek Przetwarzania Informacji (OPI) PIB (https://www.opi.org.pl). Pierwszą z nich jest serwis „Nauka Polska”, należąca do najstarszych baz tego typu, bo prowadzona od 1990 r., a udostępniona do powszechnego użytku od 1999 r. Tworzy ją pięć podstawowych kategorii danych: instytucje, ludzie nauki, prace badawcze, konferencje naukowe, targi i wystawy oraz projekty archiwalne. $Z$ tego serwisu wykorzystaliśmy materiały na temat awansów naukowych pracowników ze stopniem naukowym doktora habilitowanego i tytułem naukowym profesora oraz dane dotyczące przeprowadzonych przewodów doktorskich i habilitacyjnych w poszczególnych ośrodkach akademickich w okresie 2010-2019. Materiały te służyły bezpośrednio do analizy i ewaluacji ośrodków geograficznych oraz były wykorzystywane do weryfikacji danych zaczerpniętych z drugiej bazy - POL-on.

POL-on (https://www.polon.nauka.gov.pl) jest zintegrowanym systemem informacji o nauce i szkolnictwie wyższym, mającym częściowo charakter otwarty. Udostępniane powszechnie dane dotyczą bardzo szerokiego wachlarza informacji o nauce, począwszy od rejestru jednostek naukowych, przez ich działalność badawczo-rozwojową, po dane dotyczące projektów badawczych, nagród i wyróżnień, itp. W systemie gromadzone są również dane dotyczące polskiej bibliografii, cytowań, prac dyplomowych, ale dostęp do nich jest ograniczony i wymaga akredytacji. Z systemu „POL-on” wykorzystaliśmy szczegółowe dane dotyczące przewodów habilitacyjnych i doktorskich, dane na temat indywidualnych nagród i wyróżnień zagranicznych dla polskich naukowców za działalność naukową i naukowo-badawczą oraz informacje o projektach badawczych NCN i projektach finansowanych w ramach programu ramowego Unii Europejskiej realizowanych w ośrodkach geograficznych. 
Należy podkreślić, że w zakresie większości wykorzystanych w tym opracowaniu informacji bazy OPI są niekompletne. Jednakże są to na ogół braki jednostkowe, które stwarzają określone problemy, ale nie uniemożliwiają porównywania ośrodków akademickich. Najwięcej brakujących danych dotyczy awansów naukowych, tzn. częstym przypadkiem jest wyłącznie informacja o ostatnim awansie naukowym (rok i miejsce nadania stopnia lub tytułu naukowego) i brak informacji o wcześniej uzyskanych stopniach i ukończonych studiach. Inny problem dotyczy rozproszenia materiałów dotyczących przewodów habilitacyjnych i doktorskich. Podczas przeszukiwania bazy według jednostek akademickich, część informacji o nowszych przewodach znajduje się na tzw. aktualnych stronach ośrodków, natomiast przewody wykonane dawniej są umieszczone na „historycznych” stronach tych ośrodków. Jest to rezultat zmian strukturalnych na uczelniach i wydziałach (w ostatnich latach wyodrębniło się szereg nowych i niezależnych jednostek geograficznych). Stąd trudności w budowaniu wieloletniej i jednolitej bazy informacyjnej. Niestety należy oczekiwać dalszych zmian strukturalnych wynikających z dążeń „separatystycznych” geografów fizycznych i społecznych. Nie ułatwi to analizy baz o nauce w zakresie geografii.

Korzystaliśmy również z innych źródeł informacji, które dotyczyły osiągnięć publikacyjnych osób zatrudnionych i afiliujących poszczególne ośrodki geograficzne. Pod uwagę wzięliśmy wyłącznie publikacje osób ze stopniem doktora habilitowanego i tytułem naukowym profesora. Przyjęliśmy założenie, że wymieniona grupa pracowników ma co najmniej kilkuletnie doświadczenie zawodowe, które mogło owocować większą liczbą publikacji. Natomiast jeśli chodzi o pracowników ze stopniem doktora, byłoby zapewne wiele przypadków osób, które dopiero rozpoczynają karierę naukową i nie mogą „pochwalić” się jeszcze pokaźnym dorobkiem publikacyjnym.

Dane na temat liczby publikacji, cytowań i indeksu Hirscha pochodziły z dwóch źródeł: SCOPUS (https://www.scopus.com) i Web of Science (http://apps.webofknowledge.com). SCOPUS jest obecnie największą na świecie naukową bazą danych indeksującą wyłącznie recenzowane publikacje naukowe. Natomiast Web of Science umożliwia przeszukiwanie ponad 12000 czasopism uznawanych za najważniejsze w poszczególnych dyscyplinach naukowych. Bazy te są w polskiej literaturze naukowej szczegółowo omówione i ocenione (np. Dahlig-Turek, 2011; Kulczycki, 2017; Drabek, 2018). Dodatkowym źródłem informacji, służącym przede wszystkim weryfikacji danych, były też strony internetowe ośrodków akademickich oraz baza projektów NCN (https://www.ncn.gov.pl/).

Ocenie poddano wszystkie geograficzne jednostki akademickie realizujące badania w zakresie nowo wyodrębnionej dyscypliny geografia społeczno-ekonomiczna i gospodarka przestrzenna oraz subdyscypliny geografia fizyczna i prowadzące (z wyjątkiem jednostki PAN) studia wyższe na kierunku geografia oraz na kierunkach pokrewnych (np. gospodarka przestrzenna, turystyka, regionalistyka, itp.). Wśród nich znalazło się zatem 15 tradycyjnych ośrodków geograficznych:

- Akademia Pomorska w Słupsku (AP, Instytut Geografii i Studiów Regionalnych);

- Instytut Geografii i Przestrzennego Zagospodarowania, Polska Akademia Nauk (IGiPZ PAN);

- Uniwersytet Adama Mickiewicza w Poznaniu (UAM, Wydział Nauk Geograficznych i Geologicznych;

- Uniwersytet Gdański (UG, Instytut Geografii);

- Uniwersytet Jagielloński w Krakowie (UJ, Instytut Geografii i Gospodarki Przestrzennej); 
- Uniwersytet Jana Kochanowskiego w Kielcach (UJK, Instytut Geografii);

- Uniwersytet Kazimierza Wielkiego w Bydgoszczy (UKW, Instytut Geografii);

- Uniwersytet Łódzki (UŁ, Wydział Nauk Geograficznych);

- Uniwersytet Marii Curie-Skłodowskiej w Lublinie (UMCS, Wydział Nauk o Ziemi i Gospodarki Przestrzennej);

- Uniwersytet Mikołaja Kopernika w Toruniu (UMK, Wydział Nauk o Ziemi);

- Uniwersytet Pedagogiczny im. Komisji Edukacji Narodowej w Krakowie (UP, Instytut Geografii);

- Uniwersytet Szczeciński (US, Wydział Nauk o Ziemi);

- Uniwersytet Śląski w Katowicach (UŚ, Wydział Nauk o Ziemi);

- Uniwersytet Warszawski (UW, Wydział Geografii i Studiów Regionalnych);

- Uniwersytet Wrocławski (UWr, Instytut Geografii i Rozwoju Regionalnego).

Z badania wyłączono zakłady i katedry geografii lub gospodarki przestrzennej działające $w$ instytutach lub na wydziałach związanych z innymi dyscyplinami badawczymi (chodzi głównie o jednostki działające w uczelniach technicznych, ekonomicznych i rolniczych). W obrębie kilku spośród analizowanych ośrodków nie uwzględniono działalności instytutów, katedr, zakładów i pracowni, których tematyka badawcza dotyczy geologii lub oceanologii (ich pracownicy, w większości przypadków, deklarują te subdyscypliny, jako obszary podstawowej działalności naukowej). Taka sytuacja ma miejsce w przypadku: UAM (Instytut Geologii), UMK (Katedra Geologii i Hydrogeologii), UŚ (Katedra Geologii Podstawowej, Katedra Geologii Stosowanej, Katedra Geochemii, Mineralogii i Petrografii, Katedra Paleontologii i Stratygrafii, Katedra Hydrogeologii i Geologii Inżynierskiej), US (Zakład Geologii Morza, Zakład Paleooceanologii, Pracownia Oceanografii Fizycznej, Laboratorium Stratygrafii Geologii Historycznej). Uwzględniono natomiast jednostkowe przypadki osób zatrudnionych w jednostkach geograficznych, które deklarują „niegeograficzne" obszary zainteresowań badawczych. Należy zaznaczyć, że w kilku przypadkach ich wpływ na analizowane wskaźniki był bardzo istotny, przez co mógł on wypaczać ogólny obraz badanego ośrodka. Trudno jednak wyłączać z indywidualnych analiz badaczy, którzy są członkami geograficznych zespołów badawczych i uczestniczą w badaniach realizowanych głównie przez geografów.

Ocenę działalności naukowo-badawczej ośrodków geograficznych przeprowadzono dwuetapowo. Pierwszy etap polegał na analizie wybranych do badania cech diagnostycznych, które uwzględniły dorobek publikacyjny samodzielnych pracowników naukowych z poszczególnych ośrodków akademickich, realizowane projekty badawcze, szczególne osiągnięcia badaczy nagrodzone przez instytucje zagraniczne oraz dynamikę karier zawodowych naukowców. Zgromadzona i opracowana baza danych umożliwiła analizę następujących cech:

1) przeciętna liczba opublikowanych prac przez samodzielnych pracowników naukowych (doktorzy habilitowani i profesorowie) w ośrodku geograficznym wg bazy SCOPUS;

2) przeciętna liczba cytowań prac samodzielnych pracowników naukowych w ośrodku geograficznym wg bazy SCOPUS;

3) przeciętny h-indeks samodzielnych pracowników naukowych w ośrodku geograficznym wg bazy SCOPUS;

4) przeciętna liczba opublikowanych prac przez samodzielnych pracowników naukowych w ośrodku geograficznym wg bazy Web of Science; 
5) przeciętna liczba cytowań prac samodzielnych pracowników naukowych w ośrodku geograficznym wg bazy Web of Science;

6) przeciętny h-indeks samodzielnych pracowników naukowych w ośrodku geograficznym wg bazy Web of Science;

7) liczba projektów badawczych NCN realizowanych w okresie 2011-2019 w przeliczeniu na jednego pracownika ze stopniem naukowym doktora, doktora habilitowanego lub tytułem naukowym profesora;

8) koszt projektów badawczych NCN realizowanych w okresie 2011-2019 w przeliczeniu na jednego pracownika ze stopniem naukowym doktora, doktora habilitowanego lub tytułem naukowym profesora;

9) liczba projektów w ramach programu ramowego Unii Europejskiej;

10) przeciętny okres pomiędzy uzyskaniem stopnia doktora i doktora habilitowanego pracowników ośrodków geograficznych;

11) liczba indywidualnych nagród i wyróżnień instytucji zagranicznych w przeliczeniu na jednego samodzielnego pracownika ośrodka geograficznego wg danych POL-on.

W drugim etapie opracowano sumaryczny wskaźnik oceniający działalność naukowo-badawczą badanych ośrodków. Składał się on z trzech równoważnych cech (dorobek publikacyjny, projekty badawcze, kariera naukowa), których wartości opracowano na podstawie wybranych i wcześniej wymienionych wskaźników.

Tabela 1. Wskaźniki tworzące sumaryczną wartość cechy oceniającej działalność naukowo-badawczą ośrodków geograficznych

\begin{tabular}{|c|c|}
\hline Cecha & Wskaźniki \\
\hline $\begin{array}{l}\text { A. Dorobek publi- } \\
\text { kacyjny samodziel- } \\
\text { nych pracowników } \\
\text { naukowych }\end{array}$ & $\begin{array}{l}\text { A1) przeciętna liczba cytowań prac samodzielnych pracowników naukowych w ośrodku } \\
\text { geograficznym wg bazy SCOPUS; } \\
\text { A2) przeciętna liczba cytowań prac samodzielnych pracowników naukowych w ośrodku } \\
\text { geograficznym wg bazy Web of Science; } \\
\text { A3) przeciętna liczba opublikowanych prac przez samodzielnych pracowników nauko- } \\
\text { wych w ośrodku geograficznym wg bazy SCOPUS; } \\
\text { A4) przeciętna liczba opublikowanych prac przez samodzielnych pracowników nauko- } \\
\text { wych w ośrodku geograficznym wg bazy Web of Science. }\end{array}$ \\
\hline $\begin{array}{l}\text { B. Projekty badaw- } \\
\text { cze realizowane } \\
\text { w ośrodkach } \\
\text { geograficznych }\end{array}$ & $\begin{array}{l}\text { B1) liczba projektów badawczych NCN realizowanych w okresie 2011-2019 w przeli- } \\
\text { czeniu na jednego pracownika ze stopniem naukowym doktora, doktora habilito- } \\
\text { wanego lub tytułem naukowym profesora; } \\
\text { B2) koszt projektów badawczych NCN realizowanych w okresie 2011-2019 w przelicze- } \\
\text { niu na jednego pracownika ze stopniem naukowym doktora, doktora habilitowane- } \\
\text { go lub tytułem naukowym profesora; } \\
\text { B3) liczba projektów w ramach programu ramowego Unii Europejskiej. }\end{array}$ \\
\hline $\begin{array}{l}\text { C. Kariera nauko- } \\
\text { wa samodzielnych } \\
\text { pracowników } \\
\text { naukowych }\end{array}$ & $\begin{array}{l}\text { C1) przeciętny okres pomiędzy uzyskaniem stopnia doktora i doktora habilitowanego } \\
\text { pracowników w ośrodkach geograficznych; } \\
\text { C2) liczba indywidualnych nagród i wyróżnień instytucji zagranicznych w przeliczeniu } \\
\text { na jednego samodzielnego pracownika ośrodka geograficznego wg danych POL-on. }\end{array}$ \\
\hline
\end{tabular}

Przyjęto założenie, że wszystkie wskaźniki będą równorzędne z punktu widzenia ich wpływu na wartość cech A, B i C. W wyniku standaryzacji, maksymalnej wartości każdego wskaźnika przypisano 100 punktów. Natomiast trzem cechom (A, B, C) przyznano odpowiednie wagi; cecha A - 0,5 uznając, że dorobek publikacyjny ma największy wpływ na ocenę działalności naukowo-badawczej ośrodków geograficznych, cecha B - 0,3, zaś 
cecha $C-0,2$. Ostatecznie sumaryczny wskaźnik oceny jednostek geograficznych obliczono wg wzoru:

$$
W=0,5 A+0,3 B+0,2 C
$$

\section{Wyniki i dyskusja}

Według bazy SCOPUS, w zakresie przeciętnej liczby opublikowanych prac przez samodzielnych pracowników naukowych wyraźnie przewodzą dwa ośrodki geograficzne - Instytut Geografii i Przestrzennego Zagospodarowania PAN i Instytut Geografii i Rozwoju Regionalnego Uniwersytetu Wrocławskiego (ryc. 1). Naukowcy z tych ośrodków publikują blisko dwukrotnie więcej prac niż przeciętnie doktor habilitowany i profesor geografii w naszym kraju. O ile w IGiPZ PAN rozkład opublikowanych prac jest w miarę równomierny pomiędzy badaną grupę naukowców, to w przypadku UWr o wysokiej pozycji jednostki decydują indywidualni badacze, których można uznać za liderów. Najwięcej w kraju prac zgromadzonych w bazie SCOPUS mają:

- prof. Piotr Migoń (UWr) - 137 (geografia - geomorfologia),

- prof. Andrzej Witkowski (US) - 134 (oceanologia i geologia),

- dr hab. Maciej Kryza (UWr) - 105 (geografia - meteorologia i klimatologia),

- prof. Mariusz Lamentowicz (UAM) - 100 (geologia, biologia, geografia),

- prof. Jerzy Nawrocki (UMCS) - 96 (geofizyka).

Łatwo zauważyć, że wszyscy wymienieni reprezentują subdyscyplinę geografia fizyczna lub inne subdyscypliny z zakresu dyscypliny nauki o Ziemi i środowisku. Szczególnie dużo opracowań mają badacze specjalizujący się w klimatologii i geomorfologii. Wśród geografów społecznych najwyżej notowany prof. Jerzy Bański (IGiPZ PAN) znajduje się dopiero na 16 miejscu z liczbą 56 opublikowanych artykułów. Warto uzupełnić, że w grupie reprezentujących tę dyscyplinę zdecydowanie dominują przedstawiciele IGiPZ PAN; kolejne miejsca zajmują: dr hab. Przemysław Śleszyński (54), prof. Marek Kupiszewski (49) i prof. Piotr Korcelli (46).

Liczba cytowań wydaje się być ważniejszym od liczby opublikowanych prac wskaźnikiem na temat działalności naukowo-badawczej, bo mówi nam o znaczeniu badań i ich odbiorze przez środowisko naukowe na świecie. Pod tym względem najlepsze rezultaty mają geografowie z Wydziału Nauk Geograficznych i Geologicznych Uniwersytetu Adama Mickiewicza w Poznaniu, a następnie z IGiPZ PAN i Uniwersytetu Wrocławskiego. Należy też zaznaczyć, że w przypadku UAM, przeciętna opublikowana praca uzyskuje stosunkowo wysokie wartości cytowań, czyli jej odbiór jest szeroki. Podobnie dzieje się w przypadku prac wykonanych przez naukowców w UG i UŁ. Opracowania opublikowane przez badaczy z tych uczelni są powszechniej cytowane, niż prace wykonane w innych ośrodkach geograficznych. Na przykład przeciętna publikacja znajdująca się w bazie SCOPUS z UAM i UŁ jest cytowana 11 razy, z UG- 10 razy, zaś z UJK, UKW, AP lub UW-tylko 3 razy.

Najliczniej cytowane są prace:

- prof. Mariusza Lamentowicza (UAM) - 2383 (geologia, biologia, geografia),

- prof. Krzysztofa Fortuniaka (UŁ) - 1919 (geografia - meteorologia i klimatologia),

- prof. Zdzisława Bełki (UAM) - 1863 (geologia),

- prof. Jacka Kozaka (UJ) - 1479 (geografia - geografia fizyczna, system informacji geograficznej GIS), 
- prof. Mirosława Miętusa (UG) - 1366 (oceanologia, geofizyka).

Dla porównania pierwszy z geografów społecznych - prof. Marek Kupiszewski z liczbą cytowań 319 - znajduje się dopiero na 40. miejscu, a kolejne, lecz odległe miejsca zajmują prof. Bolesław Domański, dr hab. Przemysław Śleszyński, prof. Jerzy Bański i prof. Paweł Swianiewicz. Takie porównanie wynika tylko z faktu, iż obydwie grupy badaczy reprezentują jedną naukę - geografię - i są wspólnotą instytucjonalną. Wyciąganie głębszych wniosków z takich analiz nie ma raczej sensu, bo geografia fizyczna, wraz z geologią, oceanologią i geofizyką jest w Polsce i na świecie reprezentowana przez zdecydowanie liczniejszą grupę naukowców niż geografia społeczna, dysponujących większym zestawem czasopism naukowych. Ponadto cechą publikacji w naukach przyrodniczych jest ich wieloautorski charakter (na ogół od kilku do kilkunastu autorów), co jest raczej rzadkością w naukach społecznych. Stąd prawdopodobnie te różnice pomiędzy analizowanymi dyscyplinami.

Wyniki analizy danych zawartych w bazie Web of Sciences są odmienne, aczkolwiek wśród czołowych ośrodków pozostają takie same jak w przypadku bazy SCOPUS. Zdecydowanym liderem, zarówno pod względem opublikowanych prac w prestiżowych czasopismach naukowych, jak i liczby cytowań, jest Instytut Geografii i Rozwoju Regionalnego Uniwersytetu Wrocławskiego (ryc. 2). Wysoką pozycję tego ośrodka wypracowali wyłącznie przedstawiciele geografii fizycznej. Kolejne miejsca zajmują US, UAM, UMK, UJ, UŚ i IGiPZ PAN. W każdym z wymienionych ośrodków liczba publikacji indeksowanych w Web of Science przypadająca na jednego samodzielnego pracownika naukowego waha się od 11 do 13. Jednakże warto podkreślić, że liczba cytowań tych prac jest bardziej zróżnicowana; najkorzystniej pod tym względem wśród wymienionych jednostek wypada UJ. Jest to zasługa przede wszystkim jednego pracownika - prof. Jacka Kozaka, który zgromadził blisko 40\% wszystkich cytować samodzielnych naukowców w tym ośrodku geograficznym.

Przegląd publikacji polskich geografów w bazie Web of Science jeszcze dobitniej potwierdza dominację geografów fizycznych. Łatwo zauważyć, że stosunkowo lepsze osiągnięcia mają ośrodki, w których większy udział w strukturze zatrudnienia mają przedstawiciele tej subdyscypliny. Zdecydowanie słabiej na ich tle wypadają uczelnie, w których dużą grupę samodzielnych naukowców stanowią geografowie społeczni (UP, UŁ, UW). Po-

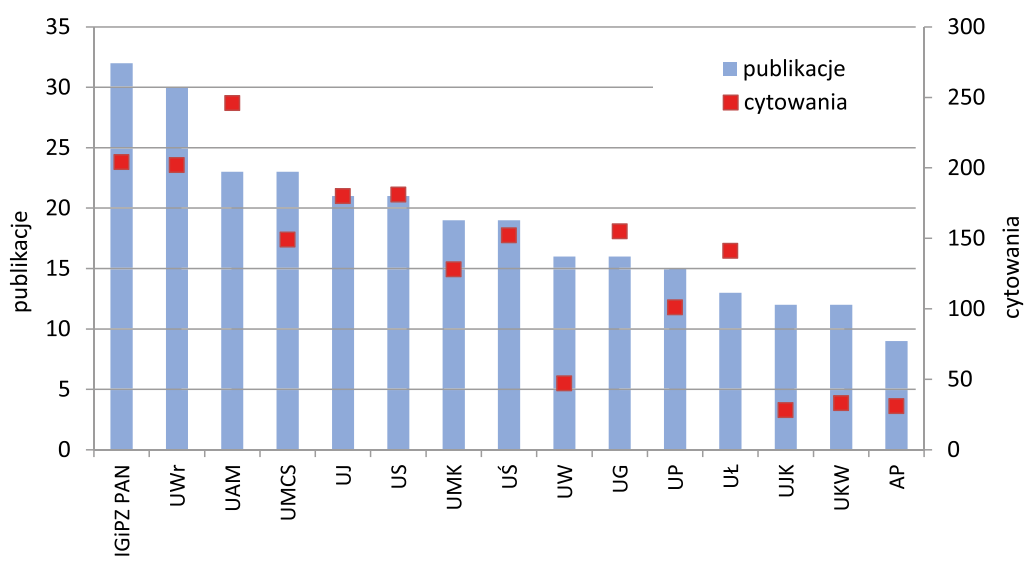

Ryc. 1. Przeciętna liczba opublikowanych prac oraz przeciętna liczba cytowań prac samodzielnych pracowników naukowych w ośrodkach geograficznym wg bazy SCOPUS (stan na 07.2019) 


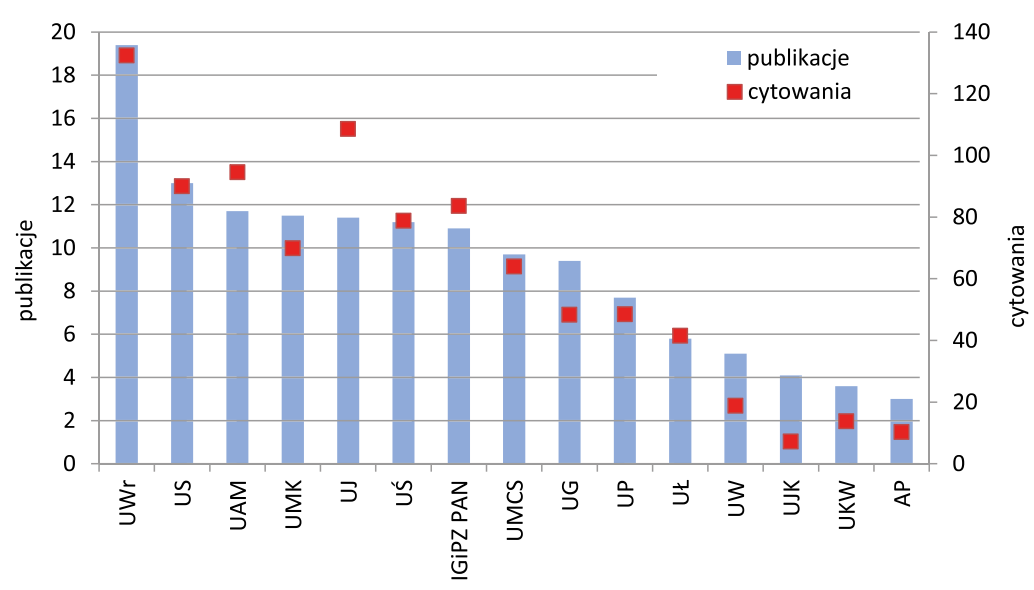

Ryc. 2. Przeciętna liczba opublikowanych prac oraz przeciętna liczba cytowań prac samodzielnych pracowników naukowych w ośrodkach geograficznym wg bazy Web of Science (stan na 07.2019)

wyższą obserwację potwierdza grupa najbardziej aktywnych geografów pod względem publikowanych prac. Wśród nich znaleźli się:

- prof. Andrzej Witkowski (US) - 98 prac (oceanologia, geologia),

- prof. Mariusz Lamentowicz (UAM) - 82 prace (geologia, biologia, geografia),

- prof. Piotr Migoń (UWr) - 74 prace (geografia - geomorfologia),

- prof. Maciej Kryza (UWr) - 70 prac (geografia - meteorologia i klimatologia),

- prof. Ireneusz Malik (UŚ) - 44 prace (geografia - geomorfologia, paleogeografia).

Podobnie jak w przypadku bazy SCOPUS, geografowie społeczni znajdują się na bardzo odległych miejscach. Wśród najliczniej cytowanych są prace prof. Marka Kupiszewskiego (IGiPZ PAN), który zajmuje wśród analizowanej grupy samodzielnych pracowników naukowych 31 miejsce. Natomiast najwyższą pozycję (35) wśród geografów społecznych pod względem liczby opublikowanych prac indeksowanych w Web of Science zajmuje prof. Paweł Swianiewicz (UW).

Badania naukowe są w coraz większym stopniu zależne od uzyskania celowych środków finansowych na ich realizację. Fundusze, którymi dysponują uczelnie i inne ośrodki badawcze, są raczej skromne i nie wystarczają na pokrycie kosztów badań realizowanych na ogół przez zespoły naukowców. Dlatego też aplikowanie o projekty badawcze jest dziś powszechnym działaniem naukowców i są one świadectwem ich aktywności na polu badawczym.

W Polsce można wskazać trzy podstawowe źródła finansowania badań naukowych, ale jest ich zdecydowanie więcej. Pierwszym i najważniejszym źródłem jest Narodowe Centrum Nauki oraz Narodowe Centrum Badań i Rozwoju, które finansują kilka różnych kategorii badań realizowanych przez indywidualnych badaczy lub ich zespoły (np. w przypadku NCN projekty Preludium, Opus, Maestro itp. zaś w przypadku NCBiR - programy strategiczne, programy międzynarodowe, programy funduszu europejskiego itp.). Drugie źródło to szeroka grupa krajowych organizacji i instytucji zlecających badania mające przede wszystkim charakter aplikacyjny (ministerstwa, samorządy, przedsiębiorstwa prywatne i państwowe itp.). Wreszcie trzecim źródłem są organizacje międzynarodowe, które często tworzą specjalne agendy, zajmujące się kształtowaniem badań naukowych (np. Ko- 
misja Europejska, finansująca wcześniejsze programy ramowe lub aktualnie realizowany Horyzont 2020). Polska w niewielkim stopniu wykorzystuje środki Unii Europejskiej przeznaczane na badania naukowe. Okazuje się, że nasz kraj wpłaca do wspólnotowej kasy dużo więcej środków na badania, niż je później wykorzystuje.

Geograficzne ośrodki akademickie wykorzystują w swoich badaniach wszystkie wymienione źródła finansowania, ale głównym źródłem jest NCN. Według danych POL-on, w okresie 2011-2019 realizowano w nich 217 takich projektów badawczych. Wśród nich były: 4 projekty ETIUDA, 2 - FUGA, 1 - MAESTRO, 18 - MINIATURA, 100 - OPUS, 1 - POLONEZ, 54 - PRELUDIUM, 28 - SONATA, 2 - SONATINA i 7 innych. Przeciętnie w analizowanym okresie projektem NCN kierował co piąty naukowiec pracujący w placówce geograficznej. Największą aktywnością w zakresie pozyskiwania projektów NCN charakteryzują się pracownicy IGiPZ PAN oraz UWr. W okresie 2011-2019 na jednego pracownika ze stopniem doktora, doktora habilitowanego lub z tytułem profesora przypadało tam odpowiednio 0,58 i 0,52 projektu badawczego NCN. Natomiast w trzech ośrodkach - UJK, UKW i AP, nie zrealizowano w analogicznym okresie ani jednego takiego projektu. Podobny rozkład ma przeciętna wartość projektu w przeliczeniu na jednego zatrudnionego pracownika naukowego (z wyłączeniem asystentów). Jeśli zaś chodzi o projekty finansowane przez Unię Europejską, to są one realizowane głównie w dwóch ośrodkach - IGiPZ PAN i UAM. W innych uczelniach takie projekty występują sporadycznie.

O aktywności naukowej świadczy również dynamika kariery zawodowej. Można przyjąć założenie, że osoby szybciej realizujące awans naukowy wykazują się większą aktywnością. Przeciętnie w kraju awans doktora geografii do stopnia doktora habilitowanego trwa blisko 13 lat. Jest to okres zdecydowanie za długi. Samodzielność naukową uzyskują osoby, które mają bliżej do emerytury niż do początku kariery naukowej. Ta niekorzystna cecha jest w dużej mierze rezultatem „minionego okresu”, bowiem znaczna część analizowanej grupy naukowców uzyskiwała swoje stopnie jeszcze przed wprowadzeniem reform w polskiej nauce. Dawniej o doktoratach, a szczególnie habilitacjach decydowali „profesorowie-mistrzowie", kierujący dużymi zespołami badawczymi. Z doświadczenia autorów tego

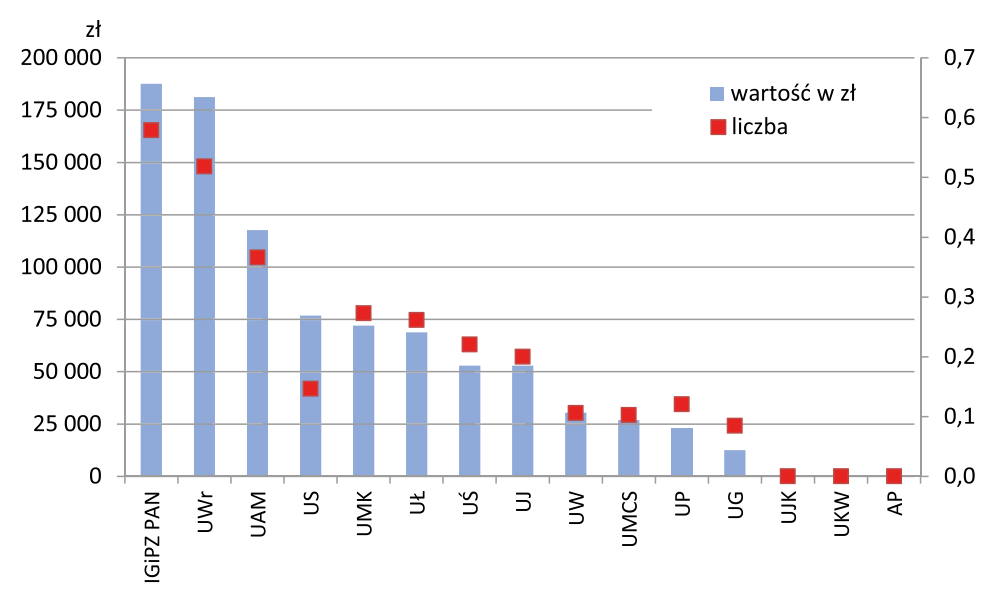

Ryc. 3. Wartość i liczba projektów badawczych NCN realizowanych w ośrodkach geograficznych okresie 2011-2019 w przeliczeniu na jednego pracownika ze stopniem naukowym doktora, doktora habilitowanego lub tytułem naukowym profesora wg stanu zatrudnienia na 2019 r. 
opracowania wynika, że kandydat aspirujący do stopnia doktora habilitowanego musiał uzyskać akceptację swojego profesora i był zazwyczaj w wieku 50+. Piszący te słowa, wnioskując o rozpoczęcie procedury habilitacyjnej w dwa lata po uzyskaniu doktoratu, spotkał się z dużą krytyką jednego z profesorów („za młody” i „za szybko”), oraz musiał przebrnąć przez wstępną ocenę pracy habilitacyjnej wykonaną przez dyrektora instytutu. Nie jest to wcale krytyka instytucji „mistrza” (szkoda, że jest ona w stadium zaniku), a raczej zwrócenie uwagi na fakt, że o karierze naukowej decydował nie sam kandydat, lecz „czynniki” zewnętrzne, nie zawsze mające charakter merytoryczny.

W całej analizowanej grupie geografów stopień doktora habilitowanego w cztery lata po uzyskaniu stopnia doktora miały tylko 4 osoby, w 5 lat - 4 osoby, 6 lat - 6 osób, 7 lat - 8 osób. Największą dynamiką w tym zakresie charakteryzują się przedstawiciele IGiPZ PAN, a następnie UKW Bydgoszcz (analiza w tym ośrodku dotyczy jednak tylko 2 osób), US i UJ Kraków (ryc. 4).

Polscy geografowie nie wykazują dużej aktywności w zakresie współpracy międzynarodowej. Dlatego też skromny jest ich dorobek jeśli chodzi o zagraniczne nagrody i wyróżnienia. Według bazy POL-on mamy w sumie zaledwie 25 indywidualnych nagród i wyróżnień za działalność naukową i naukowo-badawczą. Są to m.in. doktorat honoris causa, członkostwa honorowe, medale okolicznościowe oraz granty i stypendia. Najwięcej, bo 10, mają ich pracownicy IGiPZ PAN, a kolejne miejsca zajmują UG- 6 nagród i wyróżnień, UW-4, UWr-3, U i US- po 1. Naukowcy z pozostałych ośrodków nie mają niestety żadnych zagranicznych wyróżnień.

Analiza dziewięciu przebadanych wskaźników oraz uwzględnienie określonych wag przyjętych dla poszczególnych cech $(A-0,5, B-0,3, C-0,2)$ umożliwiła wykonanie ostatecznego rankingu badanych ośrodków geograficznych. Pierwszą grupę tworzą IGiPZ PAN, UWr i UAM, które w przypadku większości analizowanych wskaźników zajmują czołowe miejsca. Pewnym zaskoczeniem dla autorów opracowania jest wysoka pozycja ośrodka wrocławskiego. Wynika ona przede wszystkim z wysokich wskaźników dotyczących publikacji naukowych indeksowanych w bazie SCOPUS i Web of Science. Przyjmując założe-

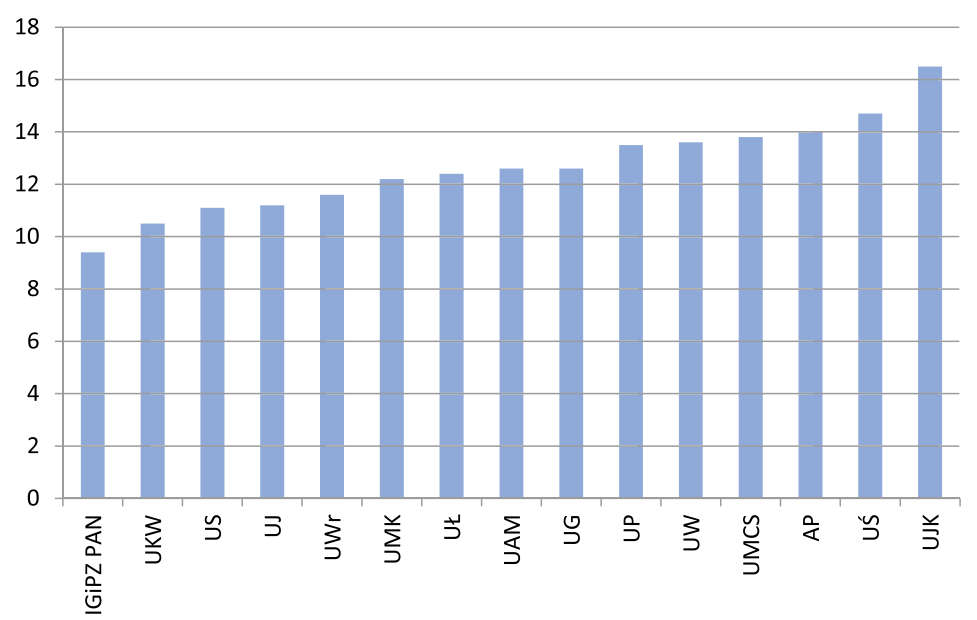

Ryc. 4. Przeciętny okres od uzyskania stopnia naukowego doktora do uzyskania stopnia naukowego doktora habilitowanego naukowców w ośrodkach geograficznych wg danych Nauki Polskiej (stan na 07.2019) 
nie, że publikacja naukowa jest najważniejszym elementem naszej działalności naukowej, należy stwierdzić, że geografia wrocławska jest aktualnym liderem naukowym w naszym środowisku. Chodzi przy tym głównie o subdyscyplinę geografia fizyczna, której przedstawiciele dominują we wszystkich rankingach dotyczących liczby opublikowanych prac, cytowań i indeksu h w prestiżowych czasopismach naukowych.

Drugą grupę tworzą pozostałe ośrodki uniwersyteckie z wyłączeniem UW. Wśród nich nieco korzystniej wypadają US i UJ, co jest przede wszystkim rezultatem pokaźnego dorobku kilku bardzo aktywnych naukowo pracowników w tych ośrodkach. Do trzeciej grupy można zaliczyć UW i UP, w których stosunkowo niższe oceny wynikają prawdopodobnie z dużej reprezentacji geografów społecznych. Jak już wcześniej stwierdzono, mają oni zdecydowanie mniejszy dorobek publikacyjny. Ostatnią grupę tworzą najmniejsze ośrodki

Tabela 2. Miejsca ośrodków geograficznych wg analizowanych wskaźników

\begin{tabular}{|l|c|c|c|c|c|c|c|c|c|}
\hline \multirow{2}{*}{$\begin{array}{c}\text { Ośrodek } \\
\text { geograficzny }\end{array}$} & \multicolumn{70}{|c|}{ Wskaźniki } \\
\cline { 2 - 10 } & A1 & A2 & A3 & A4 & B1 & B2 & B3 & C1 & C2 \\
\hline AP & 14 & 14 & 15 & 15 & $13 / 15$ & $13 / 15$ & $5 / 15$ & 13 & $7 / 15$ \\
IGiPZ PAN & 2 & 5 & 1 & 7 & 1 & 1 & $1 / 2$ & 1 & 1 \\
UAM & 1 & 3 & 3 & 3 & 3 & 3 & $1 / 2$ & $8 / 9$ & $7 / 15$ \\
UG & 6 & 10 & 10 & 9 & 12 & 12 & $5 / 15$ & $8 / 9$ & 2 \\
UJ & 5 & 2 & 5 & 5 & 7 & 8 & $5 / 15$ & 4 & $7 / 15$ \\
UJK & 15 & 15 & 13 & 13 & $13 / 15$ & $13 / 15$ & $5 / 15$ & 15 & $7 / 15$ \\
UKW & 13 & 13 & 14 & 14 & $13 / 15$ & $13 / 15$ & $5 / 15$ & 2 & $7 / 15$ \\
UŁ & 9 & 11 & 12 & 11 & 5 & 6 & $3 / 4$ & 7 & $5 / 6$ \\
UMCS & 8 & 8 & 4 & 8 & 11 & 10 & $5 / 15$ & 12 & $7 / 15$ \\
UMK & 10 & 7 & 7 & 4 & 4 & 5 & $5 / 15$ & 6 & $7 / 15$ \\
UP & 11 & 9 & 11 & 10 & 9 & 11 & $5 / 15$ & 10 & $7 / 15$ \\
US & 4 & 4 & 6 & 2 & 8 & 4 & $5 / 15$ & 3 & $5 / 6$ \\
UŚ & 7 & 6 & 8 & 6 & 6 & 7 & $5 / 15$ & 14 & $7 / 15$ \\
UW & 12 & 12 & 9 & 12 & 10 & 9 & $3 / 4$ & 11 & 3 \\
UWr & 3 & 1 & 2 & 1 & 2 & 2 & $5 / 15$ & 5 & 4 \\
\hline
\end{tabular}

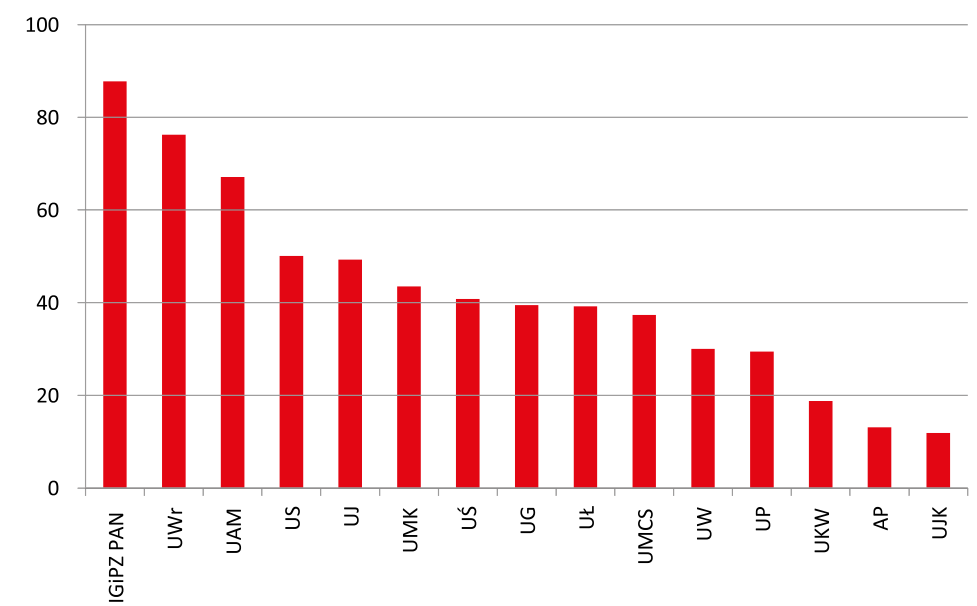

Ryc. 5. Sumaryczna ocena ośrodków geograficznych wg dziewięciu analizowanych wskaźników 
geograficzne (UKW, AP i UJK), które dysponują niewielkim potencjałem naukowym i bardzo skromną liczbowo kadrą samodzielnych pracowników naukowych.

\section{Wnioski}

Wykonana analiza prowadzi do raczej oczekiwanych wniosków. Pierwszym z nich jest fakt dużych dysproporcji ocenianych ośrodków geograficznych. Wśród 15 przebadanych jednostek, trzy z nich - IGiPZ PAN, UWr i UAM - można uznać za wiodące w zakresie analizowanych cech. Należy przy tym wyraźnie podkreślić, że zgromadzona baza danych służąca ewaluacji ośrodków akademickich jest uboga. Nie jest to wyłącznie wynik utrudnionego dostępu do materiału badawczego, lecz także braku należytej aktywności ośrodków akademickich. W przypadku projektów badawczych lub indywidualnych nagród i wyróżnień zagranicznych niektóre jednostki geograficzne charakteryzują się wartościami zerowymi. Jest to świadectwo słabnącej roli naszej dyscypliny w systemie nauki.

Pozostałe ośrodki uniwersyteckie, w przypadku większości wskaźników, lokują się w zakresie średnich wartości. Większe oczekiwania należy mieć wobec warszawskiej geografii uniwersyteckiej, która wypada słabo na tle innych ośrodków. Według rankingu Perspektyw, Uniwersytet Warszawski, jako całość, zajmuje od lat czołowe miejsce. Najsłabszą grupę tworzą mniejsze ośrodki akademickie z niewielkim potencjałem samodzielnych pracowników naukowych. Stąd trudno oczekiwać, aby ich oceny były wysokie.

Z dużym prawdopodobieństwem można przyjąć, że bez względu na zastosowane cechy diagnostyczne wynik ewaluacji byłby podobny, bowiem według przeanalizowanych dziewięciu mierników miejsce poszczególnych ośrodków w grupie 15 instytucji było podobne. Najwyżej oceniane ośrodki osiągały najwyższe wartości większości mierników i najniżej ocenione ośrodki lokowały się w przypadku wszystkich mierników na samym końcu. Odstępstwa występowały raczej sporadycznie i wynikały z przyczyn małej liczebności zbioru danych lub nietypowych przypadków (np. w ośrodku geograficznym US jeden z profesorów ma więcej cytowań w bazie SCOPUS niż wszyscy pozostali samodzielni pracownicy (14 osób), na UMCS jeden z profesorów ma liczbę cytowań równą pozostałej szóstce profesorów).

Badanie wskazuje też jednoznacznie na dysproporcje pomiędzy naukowcami reprezentującymi dwie subdyscypliny geografii. Geografowie fizyczni zdecydowanie przewodzą we wszystkich ocenach związanych z publikacjami naukowymi. Wśród nich szczególne miejsce zajmują klimatolodzy, którzy dużo publikują w prestiżowych czasopismach i są najliczniej cytowani. Dużo korzystniej na tle geografów wypadają przedstawiciele pokrewnych subdyscyplin - geofizycy, geolodzy i oceanolodzy - zatrudnieni w jednostkach geograficznych. Natomiast geografowie społeczni częściej angażują się w projekty badawcze i ekspertyzy.

Na tle ośrodków reprezentujących nauki społeczne i ekonomiczne działalność naszych jednostek jest na poziomie dostatecznym (ta opinia nie wynika z wyliczeń, lecz obserwacji, rozmów, kontaktów z przedstawicielami takich jednostek). Natomiast w porównaniu z ośrodkami badawczymi nauk ścisłych wydaje się być niedostateczna. Ocena taka ma charakter subiektywny, bo wynika tylko z obserwacji i doświadczeń autorów nie popartych analizą zagadnienia. Warto zatem wykonać kolejny krok i ocenić działalność ośrodków geograficznych na tle jednostek reprezentujących inne dyscypliny naukowe. 
Ryciny i tabele, pod którymi nie zamieszczono źródła, są opracowaniami własnymi autorów artykułu.

\section{Piśmiennictwo}

Aguillo I., Bar-Ilan J., Levene M., Ortega J.L., 2010, Comparing university rankings, Scientometrics, 85,1 , s. 243-256.

Bajerski A., 2008, Ranking ośrodków geografii społeczno-ekonomicznej w Polsce na podstawie cytowań w bazach Web of Science, Przegląd Geograficzny, 80, 4, s. 579-589.

Bański J., 2010, Stan krytyczny polskiej geografii - krytyka stanu, Przegląd Geograficzny, 82, 3, s. 319-333.

Bański J., 2015, Potencjał i aktywność kadry naukowej w polskich ośrodkach geograficznych, Przegląd Geograficzny, 87, 2, s. 279-298.

Bański J., 2017, Analiza dorobku publikacyjnego samodzielnych pracowników naukowych w polskich placówkach geograficznych, Przegląd Geograficzny, 89, 4, s. 517-538.

Cantwell B., Taylor B., 2013, Global Status, Intra-Institutional Stratification and Organizational Segmentation: A Time-Dynamic Tobit Analysis of ARWU Position Among US Universities, Minerva, 51, s. 195-223.

Dahlig-Turek E., 2011, ESF, ERIH, JCR... czyli o ewaluacji humanistyki, Kultura i Edukacja, 2, 81, s. $189-203$.

Docampo D., 2011, On using the Shanghai ranking to assess the research performance of university systems, Scientometrics, 86, 1, s. 77-92.

Drabek A., 2018, Indeksowanie czasopism w referencyjnych bazach danych, UAM, Poznań.

Jöns H., Hoyer M., 2013, Global geographies of higher education: The perspective of world university rankings, Geoforum, 46, s. 45-59.

Kulczycki E., 2017, Rola baz danych w ocenie czasopism naukowych w Polsce - aktualne cele i wyzwania polityki naukowej, [w]: Bibliograficzne bazy danych: perspektywy i problemy rozwoju: III Konferencja Naukowa Konsorcjum BazTech, Kraków, 26-27 czerwca 2017.

Millot B., 2015, International rankings: Universities vs. higher education systems, International Journal of Education Development, 40, s. 156-165.

O'Connell C., 2013, Research discourses surrounding global university rankings: exploring the relationship with policy and practice recommendation, Higher Education, 65, 6, s. 709-723.

Racki G., 2001, Najczęściej cytowane polskie publikacje z dziedziny Nauk o Ziemi z lat 90. (na podstawie National Citation Reports - Poland 1999), Przegląd Geologiczny, 49, 7, s. 584-590.

Roberts D., Thompson L., 2007, Reputation management for universities: University league tables and the impact on student recruitment, Working Paper Series, 2, The Knowledge Partnership, Leeds.

Safon V., 2013, What do global university rankings really measure? The search for the $X$ factor and the $X$ entity, Scientometrics, 97, 2, s. 223-244.

Śleszyński P., 2013, Cytowania i oddziaływanie polskich ośrodków geograficznych według Google Scholar, Przegląd Geograficzny, 85, 4, s. 599-627.

Thakur M., 2007, The impact of ranking systems on higher education and its stakeholders, Journal of Institutional Research, 13, 1, s. 83-96. 